\title{
Stress-induced behavioral changes in Iraqi dentistry academics during the COVID-19 outbreak
}

\author{
Mustafa Samir Mahmood Al-Shaikhli ${ }^{1}$, Aisha Muthanna Shanshal², Saad Abdulrahman Hussain²*
}

${ }^{1}$ Faculty of Dentistry, Al-Rafidain University College, Baghdad, Iraq, ${ }^{2}$ Aisha Muthanna Shanshal; Faculty of Pharmacy, Al-Rafidain University College, Baghdad, Iraq

\begin{abstract}
Introduction: Studies of dental practitioners performed around the world demonstrate that COVID-19 pandemic negatively impacts their daily activities lives, social functions, and health-care providing duties. The aim of the study is to evaluate the pandemic-induced psychological stress and associated factors on dental academics in Iraq.

Methods: We conduct an observational study using a self-administered survey to obtain data from dental academics in many colleges of dentistry within Baghdad city. A closed-ended questionnaire was utilized, to assess post-traumatic responses to particular events. The Impact of Event Scale was used to assess the level of stress in the first of two outcomes. The second depicts the effects of COVID-19 on behavioral changes.

Results: A total of 108 participants from seven colleges in Bagdad responded. About 38\% reported a state of severe stress, $46.3 \%$ showed moderate stress, and $13.9 \%$ complained of mild states of stress. Stress levels were found to be substantially linked to fear of infection, worries about professional responsibilities, and limited mobility.

Conclusion: The pandemic stress induces psychological and behavioral changes on the Iraqi dental educators, which can never be eliminated.
\end{abstract}

Keywords: COVID-19 pandemic; stress; dental academics; behavioral modification

\section{INTRODUCTION}

The world watched in December 2019 a rapid outbreak of hazardous virus in Wuhan, China. As a result, on March 13, 2020, the World Health Organization (WHO) declared this new strain of coronavirus sickness a pandemic after it quickly swept across China and the rest of the world (1). This has an indirect or direct impact on every part of the globe (2). Because of its deadly nature of spread and death, the COVID-19 epidemic created an emergency state over the world and widely spread in developed communities (1). The use of aerosol-generating materials or processes, such as those utilized in hospitals and dentistry clinics, increases viral transmissibility. As a result, dentistry has become one of the professions most vulnerable to COVID-19 exposure since they work in close contact with patients (3). In the light of the COVID-19 epidemic, it becomes critical to consider the potential hazards that dentists may face during daily practice $(4,5)$. According to published statistics, close contact with patients results in frequent exposure to body fluids such as blood and saliva, the dissemination

*Corresponding author: Saad Abdulrahman Hussain, Department of Pharmacology and Toxicology, Faculty of Pharmacy, Al-Rafidain University College, Baghdad 10052, Iraq. E-mail: saad.hussain@ruc.edu.iq

Submitted: 07. December 2021/Accepted: 14. February 2022

DOI: https://doi.org/10.17532/jhsci.2022.1627 of aerosols during dental treatments, and the possible propagation of viral agents in the air. Furthermore, the viral agent's persistence in operating rooms should be evaluated $(6,7)$. However, according to the published data, oral health professionals adhere to biosafety standards to a high degree (8). Other aspects and circumstances related to the COVID-19 pandemic must be evaluated, such as the amount of information available regarding the virus, preventive measures, and training programs for the treatment of the pandemic among dentists, academics, and students (9-11). Throughout the COVID-19 outbreak, dental practice has altered drastically, particularly in terms of lockdowns and isolation precautions. The disease has had a significant impact on dentists' personal life, financial standing, and professional activities, according to many studies conducted around the world $(12,13)$. Other pandemic effects include changes in family relationships as a result of the presence of children or the elderly, who can be a burden when they contribute to household income, and so on (14). Several studies have been conducted to evaluate the influence of COVID-19 on dental practitioners, dentistry students, and support personnel reporting stressful episodes, anxiety, depressive states, and other mental health markers (15-17). In addition, some research has looked into the effects of national lockdowns on dental employees' feelings of anguish and other effects (18). The Iraqi health 
authorities recorded 463,951 cases and 10,770 deaths from COVID-19 as of October 28, 2020, with dentists accounting for $2.3 \%$ of infected cases and $6 \%$ of death cases (19). The present study evaluates the pandemic-induced psychological stress and associated factors on dental academics in Iraq.

\section{METHODS}

Between March and April 2021, a self-administered survey was utilized to obtain data from dental academics in many colleges of dentistry in Baghdad for this cross-sectional observational study. The study was ethically approved by the local Research Ethics Committee of the Faculty of Pharmacy, Al-Rafidain University College (ID: REC-15-2021).

Based on a module of confidence intervals, a convenient sample of dental academics was recruited and approached directly for the study participation. The questionnaire was sent to 120 dental academics, and 108 of them submitted accurate responses. At the time of the study, the participants represented academic staff who were teaching and/or training dental students in universities or institutes. They included clinical instructors and those who agreed to provide written consent before enrolment, regardless of their academic rank. Private dentists were not invited nor were undergraduate and postgraduate students.

Based on previously reported methods, an anonymous, closed-ended questionnaire was created. Section 1 of the questionnaire comprised the 15-item Impact of Event Scale (IES) $(20,21)$, which looked at post-traumatic reactions to specific events during the COVID-19 epidemic. It has already been established as internally consistent and reliable (20). In this investigation, the Cronbach alpha was calculated to be 0.83 , showing high internal consistency. Items were rated on a 4-point Likert scale, with 0 indicating never, 1 indicating seldom, 3 indicating occasionally, and 5 indicating frequently. Using cutoff values of $0-8,9-25$, 26-43, and 44+, the overall score was calculated by summing the scores of all items and classified them as subclinical, mild stress, moderate stress, or severe stress (21). In Section 2, 16 items were used to measure the participants' perceptions of the COVID-19 impacts. Participants rated how much these items bothered them on a score of 1 (not concerned) to 10 (highly concerned) (extremely worried). Participants' agreement with two statements describing changes in behavior as a result of the COVID-19 pandemic (frequent hand washing and avoiding crowded areas) was scored in Section 3 on a scale of 1 (strongly disagree) to 10 (strongly agree). Meanwhile, Section 4 was a 9-item closedended questionnaire related to the participants' characteristics, including sex, age, country, living arrangements, highest academic ranking, coordinating courses, have clinical responsibilities, hold administrative positions, and whether they have received public health emergency training. Participants were only allowed to choose one response and make one contribution per question. The questionnaire was accompanied by a brief explanation of the study's goal, assuring participants that their responses would be kept private, and emphasizing that participation was completely voluntary. Five academics who were not involved in the research looked over the poll for face and content validity to ensure that it was clear and relevant. The questionnaire was composed entirely in English.

The data were fed into SPSS 24.0 for analysis. Frequencies, averages, percentages, and standard deviations were utilized to calculate descriptive statistics. The data appropriateness for this analysis was determined before PCA. The sampling adequacy measure of Kaiser-Meyer-Olkin (KMO) was 0.761 , which was greater than the permitted threshold (0.6). A Bartlett's test of sphericity significance value of $<0.05$ shows that the data were highly correlated (22). There were two kinds of outcomes examined. The first was a look at stress levels based on IES categories and factors that influence them. The second set of results indicated a change in behavior as a result of the COVID-19 epidemic (frequent hand washing and avoiding crowded areas, among others). The Chi-square test and Pearson's correlation were performed to see if there were any associations between stress levels and related factors and behavioral changes produced by the epidemic.

\section{RESULTS}

Responses were received from 108 participants from seven colleges in Baghdad city. About $63.9 \%$ of the participants were female, $40.7 \%$ were $25-35$ years old, $90.7 \%$ were involved in clinical practice, and $27.8 \%$ were involved in administrative positions. In addition, $38 \%$ reported severe stressful complaints, $46.3 \%$ had high stress, and $13.9 \%$ had mild stress (Table 1). Three out of 16 items were considered, with factor loadings ranging from 0.476 to 0.756 . Seven elements in the first component had loadings of $<0.75$ and were connected to infection fear. Five items in the second component had loadings of 0.717 and were related to professional duties concerns. The final component, which dealt with concerns about restricted mobility, had four items with factor loadings of $<0.635$. The most common concern about infection was that important persons will contract COVID-19 from a patient (mean $=8.1$ ). The most pressing issue concerning professional obligations during the epidemic was the requisite materials (mean $=7.27$ ). The most serious issue is that "as a result of the COVID-19 outbreak, I am missing significant events in my career" (mean $=7.84)$ (Table 2$)$. Fear of infection, concerns about professional responsibilities, and limited mobility were all significantly associated with stress levels among dental academics $(p<0.005)$, with the exception of the part about finishing reports/assignments before due dates, which was attributed to the COVID19 outbreak. In addition, the strongest direct relationship was found between stress levels and restricted mobility from one place/city to another in Iraq as a result of the COVID-19 outbreak, while the weakest relationship was found between stress levels and important others/loved ones becoming infected with COVID-19 as a result of the participant (Table 3). The factors linked to behavioral changes as a result of the COVID-19 infection and stress level are shown in Table 4. Participants agreed to avoid crowded areas $($ mean $=8.19)$ and frequent hand washing $($ mean $=8.51)$. Changes in daily routines, more frequent hand washing, and canceling social occasions were all substantially associated to stress levels, with $p=0.001,0.002$, 
TABLE 1. Personal and professional background of dental academics and their levels of COVID-19-related stress $(n=108)$

\begin{tabular}{lc}
\hline Characters & $\mathrm{n}(\%)$ \\
\hline Sex & \\
Male & $39(36.1)$ \\
Female & $69(63.9)$ \\
Age (year) & \\
25-35 & $44(40.7)$ \\
$>35-45$ & $34(31.5)$ \\
$>45-55$ & $19(17.6)$ \\
$>55-65$ & $8(7.4)$ \\
$>65-100$ & $3(2.8)$ \\
Living arrangements & \\
Alone & $18(16.7)$ \\
With parents & $35(32.4)$ \\
With partner/spouse & $53(49.1)$ \\
Shared accommodation & $0(0)$ \\
Other & $2(1.9)$ \\
Highest academic degree obtained & \\
BDS & $33(30.6)$ \\
MSc & $52(48.1)$ \\
PhD & $23(21.3)$ \\
Coordinates courses & \\
Yes & $67(62.0)$ \\
No & $41(38.0)$ \\
Has clinical responsibilities & \\
Yes & \\
No & $98(90.7)$ \\
Has administrative position & $10(9.3)$ \\
Yes & \\
No & $30(27.8)$ \\
Received training for public health emergencies & $78(72.2)$ \\
Yes & \\
No & $67(62.0)$ \\
Stress levels & $41(38.0)$ \\
Subclinical & \\
Mild & $2(1.9)$ \\
Moderate & $15(13.9)$ \\
Severe & $50(46.3)$ \\
\hline & $41(38)$ \\
\hline
\end{tabular}

and 0.000 , respectively. In the meantime, there was no statistically significant link between avoiding crowded venues and canceling trip plans $(p=0.018$ and 0.155 , respectively).

\section{DISCUSSION}

Dentists play an important role in the healthcare system. Even if this was not the case, dentistry has been described as the most stressful profession in medicine, causing more stress and anxiety than any other (23). Anxiety is typically linked to the number of hours worked and job satisfaction in non-pandemic situations $(24,25)$. The high rate of COVID-19 infection, the lack of a specific treatment for the disease, as well as misinformation and false news spread through social media are all key reasons that may cause increased stress and panic among dentists during the pandemic $(26,27)$.

Dental professionals' elevated anxiety had a negative influence on decision-making, work quality, and burnout, resulting in less than optimal patient care and a decrease in their psychological well-being $(24,28)$. According to our data, while $38 \%$ of participants experienced severe COVID-19-related traumatic stress, a multinational study found that only $9.9 \%$ of participants experienced severe stress (29).

Furthermore, many researchers have reported the influence of COVID-19 pandemic on anxiety in both pre- and post-pandemic investigations; one of these studies found that $62.5 \%$ of dentists in Chhattisgarh, India, had psychological stress, which was consistent with earlier findings (30). Another study found that the COVID-19 epidemic and ensuing lockdown increased dentists' stress levels, with $71.5 \%$ of dentists reporting stressful situations (31). Furthermore, the current study found that $61.3 \%$ of the participants expressed concern about the

TABLE 2. Principal component analysis and factor loadings for major worries and attitudes related to COVID-19 pandemic

\begin{tabular}{|c|c|c|c|c|}
\hline \multirow[t]{2}{*}{ Events } & \multirow[t]{2}{*}{ Mean (SD) } & \multicolumn{3}{|c|}{ Factor loadings } \\
\hline & & $\begin{array}{l}\text { Fear of } \\
\text { infection }\end{array}$ & $\begin{array}{l}\text { Professional } \\
\text { responsibilities }\end{array}$ & $\begin{array}{l}\text { Restricted } \\
\text { mobility }\end{array}$ \\
\hline Catching COVID-19 infection from a colleague & $6.56(2.921)$ & 0.756 & & \\
\hline Catching COVID-19 infection from a patient & $8.1(2.51)$ & 0.577 & & \\
\hline Catching COVID-19 infection from a student & $7.14(2.787)$ & 0.720 & & \\
\hline Catching COVID-19 infection from a source not related to work & $6.12(2.87)$ & 0.613 & & \\
\hline Important others getting infected with COVID-19 because of me & $7.59(2.989)$ & 0.610 & & \\
\hline $\begin{array}{l}\text { Important others getting infected with COVID-19 because of another } \\
\text { source }\end{array}$ & $7.61(2.737)$ & 0.487 & & \\
\hline Patients getting infected with COVID-19 & $7.31(2.545)$ & 0.514 & & \\
\hline Finishing open courses satisfactorily because of the COVID-19 outbreak & $5.93(2.893)$ & & 0.550 & \\
\hline Teaching students required material because of the COVID-19 outbreak & $6.73(2.747)$ & & 0.717 & \\
\hline Supporting students psychologically during the COVID-19 outbreak & $6.73(2.861)$ & & 0.476 & \\
\hline Managing online learning during the COVID-19 outbreak & $7.27(2.905)$ & & 0.596 & \\
\hline Finishing required reports/assignments during the COVID-19 outbreak & $6.79(2.795)$ & & 0.571 & \\
\hline Restricted mobility in my country because of the COVID-19 outbreak & $7.26(2.872)$ & & & 0.600 \\
\hline Restricted mobility from/to my country because of the COVID-19 outbreak & $7.45(3.061)$ & & & 0.593 \\
\hline $\begin{array}{l}\text { Restricted mobility affecting sports and social activities because of } \\
\text { COVID-19 }\end{array}$ & $7.33(2.913)$ & & & 0.566 \\
\hline $\begin{array}{l}\text { Missing events important to my career because of the COVID-19 } \\
\text { outbreak }\end{array}$ & $7.84(2.522)$ & & & 0.635 \\
\hline
\end{tabular}


TABLE 3. Factors associated with stress levels among dental academics $(n=108)$

\begin{tabular}{|c|c|c|c|}
\hline Correlation with stress level & r-value & $p$-value & Mean (SD) \\
\hline $\begin{array}{l}\text { 1. Catching COVID-19 infection } \\
\text { from a colleague at work }\end{array}$ & 0.321 & 0.001 & $6.56(2.921)$ \\
\hline $\begin{array}{l}\text { 2. Catching COVID-19 infection } \\
\text { from a patient during treatment }\end{array}$ & 0.069 & 0.000 & $8.10(2.510)$ \\
\hline $\begin{array}{l}\text { 3. Catching COVID-19 infection } \\
\text { from a student }\end{array}$ & 0.279 & 0.000 & $7.14(2.787)$ \\
\hline $\begin{array}{l}\text { 4. Catching COVID-19 infection } \\
\text { from a source not related to work }\end{array}$ & 0.277 & 0.000 & $6.12(2.870)$ \\
\hline $\begin{array}{l}\text { 5. Important others/loved ones } \\
\text { getting infected with COVID-19 } \\
\text { because of me }\end{array}$ & 0.021 & 0.000 & $7.59(2.989)$ \\
\hline $\begin{array}{l}\text { 6. Important others/loved ones } \\
\text { getting infected with COVID-19 } \\
\text { because of another source }\end{array}$ & 0.131 & 0.000 & $7.61(2.737)$ \\
\hline $\begin{array}{l}\text { 7. Patients getting infected with } \\
\text { COVID-19 }\end{array}$ & 0.173 & 0.002 & $7.31(2.545)$ \\
\hline $\begin{array}{l}\text { 8. Finishing open courses } \\
\text { satisfactorily because of the } \\
\text { COVID-19 outbreak }\end{array}$ & 0.137 & 0.000 & $5.93(2.893)$ \\
\hline $\begin{array}{l}\text { 9. Teaching students required } \\
\text { material because of the } \\
\text { COVID-19 outbreak }\end{array}$ & 0.155 & 0.000 & $6.73(2.747)$ \\
\hline $\begin{array}{l}\text { 10. Supporting students } \\
\text { psychologically in difficult times } \\
\text { of the COVID-19 outbreak }\end{array}$ & 0.215 & 0.004 & $6.72(2.861)$ \\
\hline $\begin{array}{l}\text { 11. Managing extra load required to } \\
\text { provide online learning because } \\
\text { of the COVID-19 outbreak }\end{array}$ & 0.143 & 0.000 & $7.27(2.905)$ \\
\hline $\begin{array}{l}\text { 12. Finishing required reports/ } \\
\text { assignments before important } \\
\text { deadlines because of the } \\
\text { COVID-19 outbreak }\end{array}$ & 0.191 & 0.015 & $6.79(2.795)$ \\
\hline $\begin{array}{l}\text { 13. Restricted mobility from } \\
\text { one place/city to another in } \\
\text { my country because of the } \\
\text { COVID-19 outbreak }\end{array}$ & 0.337 & 0.000 & $7.26(2.872)$ \\
\hline $\begin{array}{l}\text { 14. Restricted mobility from and } \\
\text { to my country because of the } \\
\text { COVID-19 outbreak }\end{array}$ & 0.364 & 0.013 & $7.45(3.061)$ \\
\hline $\begin{array}{l}\text { 15. Restricted mobility affecting } \\
\text { my sports and social activities } \\
\text { because of the COVID-19 } \\
\text { outbreak }\end{array}$ & 0.442 & 0.000 & $7.33(2.913)$ \\
\hline
\end{tabular}

unintentional spread of the virus to friends and their families, and became infected with COVID-19. These findings were comparable to those reported in Sarajevo, Bosnia, and Herzegovina (27). In a study performed on Iraqi physicians exposed to COVID-19 patients, 93.7\% of them showed various levels of psychological stress (32). Nonetheless, the rate of viral transmission was higher than that observed among Indians in similar circumstances (33). A recent study on Iraqi dentists found high awareness of COVID-19 symptoms, transmission pathways, and the necessary controls to keep the virus at bay in their offices (34). Another intriguing finding of the present study was that documented anxiety levels were higher among younger than older dentists and female dentists than male dentists. These findings were comparable to those reported in a study conducted in the UK (35). This is due to the fact that older dentists have more experience
TABLE 4. Association between change in behaviors due to COVID-19 and stresses, worries, COVID-19 fatality rate, and training among dental academics $(n=108)$

\begin{tabular}{|c|c|c|c|}
\hline Correlation with stress level & r value & $p$-value & Mean (SD) \\
\hline $\begin{array}{l}\text { 1. After the COVID-19 } \\
\text { outbreak, I will change my } \\
\text { life habits }\end{array}$ & 0.649 & 0.001 & $7.59(2.897)$ \\
\hline $\begin{array}{l}\text { 2. After the COVID-19 } \\
\text { outbreak, I will wash my } \\
\text { hands more frequently }\end{array}$ & 0.678 & 0.002 & $8.51(2.397)$ \\
\hline $\begin{array}{l}\text { 3. After the COVID-19 } \\
\text { outbreak, I will avoid } \\
\text { crowded places }\end{array}$ & 0.780 & 0.018 & $8.19(2.519)$ \\
\hline $\begin{array}{l}\text { 4. After the COVID-19 } \\
\text { outbreak, I will cancel } \\
\text { social events }\end{array}$ & 0.760 & 0.000 & $6.71(3.270)$ \\
\hline $\begin{array}{l}\text { 5. After the COVID-19 } \\
\text { outbreak, I will cancel travel } \\
\text { plans }\end{array}$ & 0.777 & 0.155 & $6.44(3.633)$ \\
\hline
\end{tabular}

dealing with similar pandemic scenarios than younger dentists. Furthermore, the fear of transmitting the virus to close relatives, particularly children, may elevate stress levels in female dentists more than male dentists (36). In this regard, the potential that most health-care personnel are unaware of the COVID-19 pandemic, as well as discrepancies in information sources and perceptions about the virus's natural origin (37), may lead to a condition of misunderstanding. The high levels of psychological stress experienced during the COVID-19 epidemic and accompanying lockdown could be temporary, with the situation settling down or dentists learning and adjusting to the condition. Although stress is unavoidable, it can be mitigated to some extent by employing various distraction techniques or enrolling in stress management programs, workshops, or educational initiatives (23). However, if this suffering is extreme, as it is in 38\% of dental academics, or if it persists even after COVID-19 flattens, it may have negative health consequences, demanding professional help (38). To recognize and treat emerging mental diseases, such vulnerable workers must be properly screened. Working with relevant authorities, dental key opinion leaders must design policies and guidelines that enable a stress-free environment for monitoring, screening, referral, and interventional care.

In addition, adequate exit strategies from COVID-19 lockdown for dentists should be adopted, with a focus on improved methods for infection control, rapid and effective screening and diagnostic tools, more affordable personal protective materials, and a good mental health and financial aid system.

\section{Study limitations}

The most serious flaw in the study was its self-reported bias. The response rate of the participants was not optimum. The current work was unable to determine how respondent and non-respondent dental academics differed. However, when the sociodemographic characteristics of our sample were evaluated, no statistically significant changes were found. As a result, the findings of this study can be applied to all dental academics in Baghdad area. Furthermore, the study 
was limited to dental academics working in Baghdad, the Iraqi capital. For a deeper understanding of the current model, more study should be conducted among the whole dentistry community in the country.

\section{CONCLUSION}

The vast majority of participants complain of moderate-to-severe stress. It induces psychological changes that are significantly associated with behavioral changes due to COVID-19-induced stress and concerns about the high fatality rate. Although stress cannot be completely avoided, it can be reduced to some extent by various distraction techniques. To raise their awareness, Iraqi dental educators might enroll in stress management courses, workshops, educational plans, and training programs.

\section{ACKNOWLEDGMENT}

The authors thank the Faculty of Pharmacy, Al-Rafidain University College, for supporting the project.

\section{Data sharing statement}

Supplementary data will be provided by the corresponding author based on a reasonable request.

\section{Source of fund}

No source provided.

\section{DECLARATION OF INTERESTS}

The authors declare no conflicts of interest.

\section{REFERENCES}

1. Pillai S, Siddika N, Hoque Apu E, Kabir R. COVID-19: Situation of European countries so far. Arch Med Res 2020;51(7):723-5 https://doi.org/10.1016/j.arcmed.2020.05.015

2. Chang SL, Harding N, Zachreson C, Cliff OM, Prokopenko M. Modelling transmission and control of the COVID-19 pandemic in Australia. Nat Commun 2020;11:5710. https://doi.org/10.1038/s41467-020-19393-6

3. Polednik B. Aerosol and bioaerosol particles in a dental office. Environ Res 2014;134:405409.

https://doi.org/10.1016/j.envres.2014.06.027

4. Bizzoca ME, Campisi G, Muzio LL. COVID-19 pandemic: What changes for dentists and oral medicine experts? A narrative review and novel approaches to infection containment. Int J Environ Res Public Health 2020;17(11):3793. https://doi.org/10.3390/ijerph17113793

5. Cabrera-Tasayco FD, Rivera-Carhuavilca JM, Atoche-Socola KJ, Peña-Soto C Arriola-Guillen LE. Biosafety measures at the dental office after the appearance of COVID-19: A systematic review. Disaster Med Public Health Prep 2020;15(6):e34-8. https://doi.org/10.1017/dmp.2020.269

6. Turkistani KA, Turkistani KA. Dental risks and precautions during COVID-19 pandemic: A systematic review. J Int Soc Prev Community Dent 2020;10(5):540-8. https://doi.org/10.4103/jispcd.JISPCD_295_20

7. Montalli VA, Garcez AS, de Oliveira LV, Sperandio M, Napimoga MH, Motta RH A novel dental biosafety device to control the spread of potentially contaminated dispersion particles from dental ultrasonic tips. PLoS One 2021;16(2):e0247029. https://doi.org/10.1371/journal.pone.0247029

8. Rossato MDS, Gregorio D, de Almeida-Pedrin RR, Maia LP, Poli RC, Berger SB, et al Evaluation of dental practices changes during the COVID-19 pandemic in Brazil. Eval Health Prof 2021;44:192-7.

https://doi.org/10.1177/0163278721994902

9. Almulhim B, Alassaf A, Alghamdi S, Alroomy R, Aldhuwayhi S, Aljabr A, et al. Dentistry amidst the COVID-19 pandemic: Knowledge, attitude, and practices among the Saudi Arabian dental students. Front Med (Lausanne) 2021:8:654524.

https://doi.org/10.3389/fmed.2021.654524

10. Boukhobza S, Ritschl V, Stamm T, Bekes K. The COVID-19 Pandemic and its impact on knowledge, perception and attitudes of dentistry students in Austria: A cross-sectional survey. J Multidiscip Healthcare 2021;14:1413-22.

https://doi.org/10.2147/JMDH.S311535

11. Amato A, Ciacci C, Martina S, Caggiano M, Amato M. COVID-19: The dentists' perceived impact on the dental practice. Eur J Dent 2021;15(3):469-74 https://doi.org/10.1055/s-0040-1721910

12. Ahmadi $\mathrm{H}$, Ebrahimi A, Ghorbani F. The impact of COVID-19 pandemic on dental practice in Iran: A questionnaire-based report. BMC Oral Health 2020;20(1):354. https://doi.org/10.1186/s12903-020-01341-x

13. Baracco B, Ceballos L, Llorente A, Fuentes MV. Impact of COVID-19 on the work of Spanish dentists: An early response to the pandemic. J Clin Exp Dent 2021;13(2):e148-55. https://doi.org/10.4317/jced.57941

14. Wang C, Horby PW, Hayden FG, Gao GF. A novel coronavirus outbreak of global health concern. Lancet 2020;395(10223):470-3. https://doi.org/10.1016/S0140-6736(20)30185-9

15. Agius AM, Gatt G, Zahra EV, Busuttil A, Gainza-Cirauqui ML, Cortes AR, et al. Selfreported dental student stressors and experiences during the COVID-19 pandemic. J Dent Educ 2021;85(2):208-15.

https://doi.org/10.1002/jdd.12409

16. Sarapultseva M, Zolotareva A, Kritsky I, Nasretdinova N, Sarapultsev A. Psychological distress and post-traumatic symptomatology among dental healthcare workers in Russia: Results of a pilot study. Int J Environ Res Public Health 2021;18(2):708. https://doi.org/10.3390/ijerph18020708

17. Mekhemar M, Attia S, Dörfer C Conrad J. The psychological impact of the COVID-19 pandemic on dentists in Germany. J Clin Med 2021;10(5):1008. https://doi.org/10.3390/jcm10051008

18. Collin V, Selmo EO, Whitehead P. Psychological distress and the perceived impact of the COVID-19 pandemic on UK dentists during a national lockdown. Br Dent J 2021; Online ahead of print. 1-8.

19. Albujeer AN. COVID-19 impact on dental education in Iraq: Challenges and future implications. J Contemp Med Sci 2020;6(5):255.

20. Horowitz M, Wilner N, Alvarez W. Impact of event scale: A measure of subjective stress. Psychosom Med 1979;41:209-18.

21. Skevington SM, Böhnke JR. How is subjective well-being related to quality of life? Do we need two concepts and both measures? Soc Sci Med 2018;206:22-30. https://doi.org/10.1016/j.socscimed.2018.04.005

22. Tobias S, Carlson JE. Brief report: Bartlett's test of sphericity and chance findings in factor analysis. Multivariate Behav Res 1969;4(3):375-7. https://doi.org/10.1207/s15327906mbr0403_8

23. Ayers KM, Thomson WM, Newton JT, Rich AM. Job stressors of New Zealand dentists and their coping strategies. Occup Med (Lond) 2008;58(4):275-81. https://doi.org/10.1093/occmed/kgn014

24. Chipchase SY, Chapman HR, Bretherton R. A study to explore if dentists' anxiety affects their clinical decision-making. Br Dent J 2017;222:277-90

25. Song KW, Choi WS, Jee HJ, Yuh CS, Kim YK, Kim L, et al. Correlation of occupational stress with depression, anxiety, and sleep in Korean dentists: Cross-sectional study. BMC Psychiatry 2017:17(1):398 https://doi.org/10.1186/s12888-017-1568-8

26. Mackolil J, Mackolil J. Addressing psychosocial problems associated with the COVID-19 lockdown. Asian J Psychiatr 2020;51:102156. https://doi.org/10.1016/j.ajp.2020.102156

27. Ajanović M, Pošković ST, Kožul K, Kamber-Ćesir A, Đonlagić A, Kacila M, et al. Knowledge of coronavirus 2019 and stress with oral health-care personnel of the Faculty of dentistry in Sarajevo: A cross-sectional study. J Health Sci 2021;11(1):47-52. https://doi.org/10.17532/jhsci.2020.1073

28. Kang L, Li Y, Hu S, Chen M, Yang C, Yang BX, et al. The mental health of medical workers in Wuhan, China dealing with the 2019 novel Coronavirus. Lancet Psychiatry 2020;7(3):e14. https://doi.org/10.1016/S2215-0366(20)30047-X

29. Ammar N, Aly NM, Folayan MO, Khader Y, Virtanen JI, Al-Batayneh OB, et al. Behavior change due to COVID-19 among dental academics-the theory of planned behavior: Stresses, worries, training, and pandemic severity. PLoS One 2020;15(9):e0239961. https://doi.org/10.1371/journal.pone.0239961

30. Mishra S, Singh S, Tiwari V, Vanza B, Khare N, Bharadwaj P. Assessment of level of perceived stress and sources of stress among dental professionals before and during the COVID -19 outbreak. J Int Soc Prev Community Dent 2020;10(6):794-802. https://doi.org/10.4103/jispcd.JISPCD_340_20

31. Lai J, Ma S, Wang Y, Cai Z, Hu J, Wei N, et al. Factors associated with mental health outcomes among health care workers exposed to coronavirus disease 2019. JAMA Netw Open 2020;3(3):e203976.

https://doi.org/10.1001/jamanetworkopen.2020.3976

32. Abdulah DM, Musa DH. Insomnia and stress of physicians during COVID-19 outbreak. Sleep Med X 2020;2:100017.

https://doi.org/10.1016/.sleepx.2020.100017 
33. Roy D, Tripathy S, Kar SK, Sharma N, Verma SK, Kaushal V. Study of knowledge, attitude, anxiety and perceived mental healthcare need in Indian population during COVID-19 pandemic. Asian J Psychiatr 2020;51:102083

https://doi.org/10.1016/j.ajp.2020.102083

34. Sabea DW. Evaluation of responsiveness, adaptation \& alertness for sample of Iraq dentists during COVID-19 crunch: Sample from Baghdad City. Syst Rev Pharmacy 2021;12(2):209-18.

35. Jordan RE, Adab P, Cheng K. COVID-19: Risk factors for severe disease and death. BMJ 2020;368:m1198.

https://doi.org/10.1136/bmj.m1198
36. Mahdee AF, Gul SS, Abdulkareem AA, Qasim SSB. Anxiety, practice modification, and economic impact among Iraqi dentists during the COVID-19 outbreak. Front Med 2020;7:595028.

https://doi.org/10.3389/fmed.2020.595028

37. Maestro D, Šegalo S, Remić D, Pašalić A, Jogunčić A. COVID-19 pandemic: A challenge for health-care professionals and assessment of anxiety symptoms. J Health $\mathrm{Sci}$ 2020;10(3):211-8.

https://doi.org/10.17532/jhsci.2021.1291

38. Phillips MR. Is distress a symptom of mental disorders, a marker of impairment, both or neither? World Psychiatry 2009;8(2):91-2.

\section{RELATED ARTICLES PUBLISHED IN JHSCI}

1. Ajanović M, Pošković ST, Kožul K, Kamber-Ćesir A, Đonlagić A, Kacila M, et al. Knowledge of coronavirus 2019 and stress with oral health-care personnel of the Faculty of dentistry in Sarajevo: A cross-sectional study. J Health Sci 2021;11(1):47-52.

2. Maestro D, Šegalo S, Remić D, Pašalić A, Jogunčić A. COVID-19 pandemic: A challenge for health-care professionals and assessment of anxiety symptoms. J Health Sci 2020;10(3):211-8 